\title{
The Migration of Chemical Contaminants from Polyethylene Bags into Food During Cooking
}

\author{
L. Musoke ${ }^{a}$, N. Banadda ${ }^{\text {b }}$ C. Sempala ${ }^{\text {c,** }}$ and J. Kigozi ${ }^{\mathrm{b}}$ \\ ${ }^{a}$ Department of Food Technology and Nutrition, Makerere University, P.O. Box 7062 Kampala, Uganda \\ ${ }^{b}$ Department of Agricultural and Bio-Systems Engineering, Makerere University, P.O. Box 7062 Kampala, Uganda \\ ${ }^{c}$ Department of Educational Foundations and Curriculum, Makerere University, P.O. Box 7062 Kampala, Uganda
}

\begin{abstract}
Cooking food in polyethylene bags has of late substituted banana leaves in Uganda. However, such a practice is risky as chemical contaminants may migrate from polyethylene bags into food during cooking causing health complications. Therefore, this study was done to identify and quantify the levels of chemical contaminants (heavy metals) in black and green polyethylene bags. Polyethylene bags were ashed and digested with acid and heavy metal concentrations determined using an AAS. Samples analyzed contained heavy metals with concentrations ranging between; 1125 - 1725, 76 - 112, 35 - 52, 18 - $31 \mathrm{ppm}$ for $\mathrm{Pb}, \mathrm{Cd}, \mathrm{Cr}$ and Co respectively. Heavy metal migration studies into posho cooked in the black polyethylene bags was done at $65^{\circ} \mathrm{C}\left(\mathrm{T}_{1}\right), 80^{\circ} \mathrm{C}\left(\mathrm{T}_{2}\right)$ and $95^{\circ} \mathrm{C}\left(\mathrm{T}_{3}\right)$. The highest migrated heavy metal concentrations 120.60, 12.25, 9.45 and $15.42 \mathrm{ppm}$ for $\mathrm{Pb}, \mathrm{Cd}, \mathrm{Cr}$ and Co respectively were obtained at $\mathrm{T}_{3}$ at the surface of the posho cube $(0.5 \mathrm{~cm})$ after 5 hours of heating. While the lowest values for $\mathrm{Pb}(10.60 \mathrm{ppm}), \mathrm{Cd}(1.26 \mathrm{ppm}), \mathrm{Cr}(0.20 \mathrm{ppm})$ and $\mathrm{Co}(1.55 \mathrm{ppm})$ were obtained at $\mathrm{T}_{1}$ towards the centroid of the posho cube $(1.5 \mathrm{~cm})$ after 2 hours of heating. $\mathrm{Pb}$ migrated highest followed by $\mathrm{Co}, \mathrm{Cr}$ and $\mathrm{Cd}$. Though small quantities migrated, over a long period of time they may accumulate in the body and cause health complications to the victims. To make this research of substantial importance to the polyethylene bag user, the findings were disseminated through media to the general public.
\end{abstract}

Keywords: Heavy metals, Migration, Polyethylene bags, Posho.

\section{INTRODUCTION}

For years, food has been traditionally cooked and kept warm by wrapping it in banana leaves across many communities in Uganda. However, due to climatic changes coupled with changing life style among urban people, food vendors, and some households, wrapping of food in colored low density polyethylene bags during cooking is on the rise. This might be due to the fact that polyethylene bags are cheap, durable, flexible and easy to use [1]. Furthermore, [2] argues that polyethylene bags have high thermo-seal ability and barrier properties to water. This makes them an alternative to banana leaves as the food vendors are sure of serving a hot meal all day long. Despite all the advantages of polyethylene bags, a number of studies have suggested that polyethylene materials contain a wide range of potential chemical migrants like residual monomers, low-molecularweight polymers (oligomers) and additives (plasticizers, stabilizers, slip agents, block agents, colourants, fillers, lubricants etc.) that can migrate into food during cooking. These additives are added during production of polyethylene bags to achieve specific properties [3-9].

The interest in some of the additives arises from their known acute and chronic toxicity when exposed to humans

*Address correspondence to this author at the Department of Educational Foundations and Curriculum, Makerere University; P.O. Box 7062 Kampala, Uganda; E-mail: cssempala@educ.mak.ac.ug with no effective mechanism for their elimination from the body $[4,8,10,11]$. Metal ions such as lead and cadmium absorbed from food poses a possibility of bioaccumulation in body tissues and with excessive intake they may lead to healthy complications such as abdominal pain, anaemia, ataxia and memory loss $[8,11]$.

Therefore, this study aims to identify and quantify the amount of chemical contaminants heavy metals in particular that migrate into food during thermal processing. It's also anticipated that this study shall educate and create awareness among the general population through sharing the outcomes with the relevant stakeholders.

\section{MATERIALS AND METHODS}

\subsection{Heavy Metal Analysis in Polyethylene Bags}

Plasto-Foam brand, size 22 and 25 gauge of 30 micrometer thickness commonly used for wrapping foodstuffs were cut into pieces and placed in large silica crucibles. The pieces were then charred on a hot plate until the fume ceased to exist. This was then followed by complete ashing in furnace. The crucible was then taken out of the furnace and cooled. After cooling, the sample was homogenized and $1 \mathrm{~g}$ of the sample taken in separate silica crucible for acid digestion. Analytical grade Nitric acid $(65 \%)$ and Hydrogen peroxide $(30 \%)$ was used for digestion in an open vessel. The digest was then filtered through a filter paper to remove 
the insoluble particles and brought to a final volume of $50 \mathrm{ml}$ with distilled deionized water. The resultant solution was then analyzed using the Atomic Absorption Spectrophotometer to determine heavy metal $(\mathrm{Pb}, \mathrm{Cd}, \mathrm{Cr}$ and $\mathrm{Co}$ ) concentrations.

\subsection{Analysis of Heavy Metal Migration Into Posho from Polythene Bags}

Heavy metal migration studies were carried out on posho cooked in the black polyethylene bags.

\subsubsection{Posho Preparation}

Posho was conventionally mingled as it's done by food vendors. Approximately $250 \pm 0.5 \mathrm{~g}$ of grade one posho together with $600 \mathrm{mls}$ of distilled and de-ionized water was mingled by use of a charcoal stove. Once ready, it was wrapped in both black (Plasto foam size 22) and green (Plasto foam size 25, +30 microns) polyethylene bags then immersed into pre-set water baths (Grant instruments, Cambridge England) at $65^{\circ} \mathrm{C}, 80^{\circ} \mathrm{C}$, and $95^{\circ} \mathrm{C}$. The temperature of the water baths was continuously monitored by use of a calibrated thermometer.

\subsubsection{Heavy Metal Migration Analysis}

Three samples from the black polyethylene bags were scooped by use of a fabricated square stainless steel mould $(5 \times 5 \mathrm{~cm})$ after 2 , and 5 hours of heating. From the scooped posho cubes, slices of length $0.5 \mathrm{~cm}, 1.0 \mathrm{~cm}$ and $1.5 \mathrm{~cm}$ were cut starting from the surface that was in contact with the polyethylene bag towards the centroid of the posho cube. The slices were then dried in an oven (Gallenkamp, UK serial number: S093/08/580) and ground uniformly into a powder by use of a blender (Philips NL9206AD-4 Drachten, China).

A method by [12] was used for analysis of heavy metals in posho samples. Approximately $0.3 \pm 0.05 \mathrm{~g}$ of the powder was weighed into the digesting tubes and $6 \mathrm{mls}$ of the digesting mixture added. The digesting tubes with their content were then heated in the digesting bloc set at $350^{\circ} \mathrm{C}$ in the fumehood until clear solutions were obtained. During the course of heating hydrogen peroxide $(30 \%)$ solution was used to clear digesting tube walls of scattered mixture. The clear solutions were then cooled and $10 \mathrm{mls}$ of de-ionized water added. The solutions were then transferred into glass bottles and analyzed for heavy metals using Atomic Absorption Spectrophotometer (Perkin-Elmer 2380). The obtained value $(\mathrm{mg} / \mathrm{l})$ for heavy metal concentrations were converted to parts per million by equation (1):

$\mathrm{ppm}=\frac{v o l \times \alpha \times d f}{w t}$

Where $\alpha$ is value of heavy metal concentration in $\mathrm{mg} / \mathrm{l}$, vol is the volume of the volumetric flask, $\mathrm{df}$ is the dilution and wt is the weight of sample

\section{RESULTS AND DISCUSSIONS}

\subsection{Heavy Metals in Polyethylene Bags}

The results for the heavy metal concentration in the Low Density Polyethylene bag samples are presented in Table 1. Both green and black polyethylene bag samples were analyzed for heavy metals.

All the low density polyethylene bag samples analyzed were found to contain Lead, Cadmium, Chromium and Cobalt in varying concentration levels. The results ranged from 1725 - 1125, 120 - 76, 50 - 36, 32 - 18 ppm for $\mathrm{Pb}, \mathrm{Cd}$, $\mathrm{Cr}$ and Co respectively. The results are comparable to most of the results presented by [13] where plastic toys were analyzed for heavy metals but with the maximum mean concentrations for $\mathrm{Pb}$ (1445 ppm), Cd (373.33 ppm), $\mathrm{Cr}$ (191.67 ppm) and Co (73.33 ppm) being a little higher than the ones observed; $\mathrm{Pb}(1725 \mathrm{ppm}), \mathrm{Cd}$ (120 ppm), $\mathrm{Cr}$ (50 ppm) \& Co $(32 \mathrm{ppm})$ in this study. Though with high difference in the means between the two studies, mean values of this study showed little variation than [13] and this might be due to the similarity of the samples analyzed in both studies. Furthermore, a study by [8] showed higher concentrations of Lead and Cadmium in some Nigerian confection wrappers with the highest concentration, which conquers with results obtained in this study. Generally the

Table 1. Mean (SD) for heavy metal concentration (ppm) in polyethylene samples.

\begin{tabular}{|c|c|c|c|c|}
\hline Green Samples & Pb (ppm) & Cd (ppm) & Cr (ppm) & Co (ppm) \\
\hline \hline 1 & $1333 \pm 60.83$ & $88 \pm 23.45$ & $35 \pm 15.4$ & $25 \pm 0.180$ \\
\hline 2 & $1245 \pm 42.14$ & $85 \pm 16.23$ & $37 \pm 12.12$ & $28 \pm 14.77$ \\
\hline 3 & $1080 \pm 43.16$ & $78.23 \pm 28$ & $36 \pm 28.72$ & $18 \pm 13.24$ \\
\hline 4 & $1125 \pm 47.82$ & $76 \pm 22.43$ & $\mathbf{C r}(\mathbf{p p m})$ & $30 \pm 14.04$ \\
\hline \hline Black Samples & $\mathbf{P b}(\mathbf{p p m})$ & $\mathbf{C d}(\mathbf{p p m})$ & $45 \pm 16.10$ & $32 \pm 14.40$ \\
\hline 5 & $1725 \pm 62.78$ & $112 \pm 35.62$ & $48 \pm 29.12$ & $50 \pm 19.41$ \\
\hline 7 & $1545 \pm 49.23$ & $120 \pm 25.34$ & $98 \pm 14.23$ & $52 \pm 14.31$ \\
\hline
\end{tabular}

Data are mean values of triplicate samples \pm standard deviation. 
black polyethylene bag samples showed higher concentrations of all the chemical contaminants $(\mathrm{Pb}, \mathrm{Cd}, \mathrm{Cr}$ \& Co) analyzed than green polyethylene bags. The difference between green and black samples might be due to the difference in the formulations used during their manufacture. Lead showed the highest concentration in both green and black polyethylene bag samples followed by Cadmium Chromium and Cobalt last. However, with no set concentration standards for usage of heavy metal compounds, the results obtained in this study could not be compared to determine whether they are below or above recommended levels. However, when compared with standard EU Directive 94/62/EC (amended by 2004/12/EC) on Packaging and Packaging Waste that sets out a maximum limit of $100 \mathrm{mg} / \mathrm{kg}$ for all $\mathrm{Pb}, \mathrm{Cd}, \mathrm{Cr}$ (VI), and $\mathrm{Hg}$, the results were higher showing a risk faced by the people who eat food wrapped in polyethylene bags.

\subsubsection{Correlation Analysis}

Furthermore, a correlation analysis for heavy metals in both black and green samples was done to find out if some heavy metals were interrelated and the results are presented in Tables 2 and 3. There was both positive and negative correlation at $\mathrm{P} 0.1$ between $\mathrm{Pb}, \mathrm{Cd}, \mathrm{Cr}$ and $\mathrm{Co}$ for both black and green polyethylene bags.

The positive correlation observed in this study, is in agreement with [13] that studied correlation among heavy metals in toys- while the negative correlation is in agreement with [8] that observed a negative correlation between the concentration of $\mathrm{Pb}$ and $\mathrm{Cd}$ in some Nigerian confection wrappers. The positive correlation may indicate a significant influence of one metal on another.

There is a possibility of metals coming from the same source such as stabilizers, plasticizers used in the production of polyethylene bags to achieve specific objectives. Therefore removal of one heavy metal may affect the performance of another. Because the correlation coefficient between $\mathrm{Pb}$ and $\mathrm{Cr}, \mathrm{Cr}$ and $\mathrm{Co}$ in green polyethylene samples and $\mathrm{Cr}$ and $\mathrm{Co}$ in black polyethylene bag were high, it can then be argued that $\mathrm{Pb}, \mathrm{Cr}$ and $\mathrm{Co}$ were used as additives in polyethylene bags. The negative correlation between $\mathrm{Cd}$ and the other three heavy metals may indicate its

Table 2. Correlation among heavy metals in black polyethylene bags.

\begin{tabular}{|c|c|c|c|c|}
\hline Sample & Pb & Cd & Cr & \\
\hline \hline $\mathrm{Pb}$ & 1 & & & \\
\hline $\mathrm{Cd}$ & -0.882 & 1 & 1 & \\
\hline $\mathrm{Cr}$ & 0.373 & -0.672 & 0.687 & 1 \\
\hline $\mathrm{Co}$ & -0.390 & -0.049 & & 1 \\
\hline
\end{tabular}

Correlation is significant at the 0.1 level (2-tailed).

Table 3. Correlation among heavy metals in green polyethylene bags.

\begin{tabular}{|c|c|c|c|c|}
\hline Sample & Pb & Cd & Cr & \\
\hline \hline $\mathrm{Pb}$ & 1 & & & \\
\hline $\mathrm{Cd}$ & -0.898 & 1 & 1 & \\
\hline $\mathrm{Cr}$ & 0.949 & -0.719 & 0.803 & 1 \\
\hline $\mathrm{Co}$ & 0.603 & -0.194 & & \\
\hline
\end{tabular}

Correlation is significant at the 0.1 level (2-tailed).

Table 4. Heavy metal migration into posho at treatment temperature, $T_{1}$.

\begin{tabular}{|c|c|c|c|c|c|}
\hline \multirow[t]{2}{*}{ Time } & \multirow[t]{2}{*}{ Position } & \multicolumn{4}{|c|}{ Heavy Metals (ppm) } \\
\hline & & $\mathbf{P b}$ & Cd & $\mathrm{Cr}$ & Co \\
\hline \multirow[t]{3}{*}{$2 \mathrm{hrs}$} & $1(0.5 \mathrm{~cm})$ & $19.68 \pm 0.38$ & $3.12 \pm 0.20$ & $2.38 \pm 0.04$ & $3.21 \pm 0.03$ \\
\hline & $2(1.0 \mathrm{~cm})$ & $12.47 \pm 0.46$ & $2.64 \pm 0.32$ & $1.61 \pm 0.25$ & $2.22 \pm 0.13$ \\
\hline & $3(1.5 \mathrm{~cm})$ & $10.60 \pm 1.69$ & $1.26 \pm 0.03$ & $0.20 \pm 0.17$ & $1.55 \pm 0.19$ \\
\hline \multirow[t]{3}{*}{$5 \mathrm{hrs}$} & 1 & $55.34 \pm 1.70$ & $5.56 \pm 0.61$ & $6.51 \pm 0.05$ & $5.89 \pm 0.02$ \\
\hline & 2 & $21.47 \pm 0.50$ & $4.66 \pm 0.29$ & $3.73 \pm 0.17$ & $3.53 \pm 0.04$ \\
\hline & 3 & $11.33 \pm 0.68$ & $3.03 \pm 0.16$ & $1.37 \pm 0.15$ & $2.13 \pm 0.20$ \\
\hline
\end{tabular}


minimal influence on the performance of the other three heavy metals.

\subsection{Heavy Metal Migration in Posho Wrapped in Black Polyethylene Bag}

The results for heavy metal migration from black polyethylene bag into posho at treatment temperatures, $65^{\circ} \mathrm{C}$ $\left(\mathrm{T}_{1}\right), 80^{\circ} \mathrm{C}\left(\mathrm{T}_{2}\right), 95^{\circ} \mathrm{C}\left(\mathrm{T}_{3}\right)$ are presented in Tables 4-6. Migration of the heavy metals studied occurred at all treatment temperatures in varying concentrations. It increased with increase in treatment temperature $\left(\mathrm{T}_{1}<\mathrm{T}_{2}<\right.$ $\mathrm{T}_{3}$ ) and holding time $(2 \mathrm{hrs}<5 \mathrm{hrs})$ and decreased with depth as the centroid of posho cube $(1.5 \mathrm{~cm}<1.0 \mathrm{~cm}<0.5 \mathrm{~cm})$ was approached. With treatment temperature, $\mathrm{T}_{3}$ having the highest concentrations of all migrated heavy metal followed by $\mathrm{T}_{2}$ and then $\mathrm{T}_{1}$. The highest values for $\mathrm{Pb}(120.60 \mathrm{ppm})$, Cd (12.25 ppm), Cr (9.45 ppm) and Co (15.42 ppm) were obtained at treatment temperature, $\mathrm{T}_{3}$ at the surface of the posho cube $(0.5 \mathrm{~cm})$ after 5 hours of heating (Table 6). While the lowest values for $\mathrm{Pb}(10.60 \mathrm{ppm}), \mathrm{Cd}(1.26 \mathrm{ppm}), \mathrm{Cr}$ $(0.20 \mathrm{ppm})$ and Co $(1.55 \mathrm{ppm})$ were obtained at treatment temperature, $T_{1}$ towards the centroid of the posho cube (1.5 $\mathrm{cm}$ ) after 2 hours of heating (Table 4).

$\mathrm{Pb}$ had the highest migration followed by Co which was closely followed by $\mathrm{Cr}$ and then $\mathrm{Cd}$ had the lowest migration. However, when the highest migrated heavy metal concentrations $(\mathrm{Pb}(120 \mathrm{ppm}), \mathrm{Cd}(12.25 \mathrm{ppm}), \mathrm{Cr}(9.45$ $\mathrm{ppm}$ ), Co (15.42 ppm) (Table 6)) were compared to their respective highest concentrations in black polyethylene bags ( $\mathrm{Pb}$ (1725 ppm), Cd (52 ppm), Cr (120 ppm), Co (32 ppm) (Table 1)), it showed that $48 \%, 16 \%, 8 \%$ and $7 \%$ of $\mathrm{Co}, \mathrm{Cd}$, $\mathrm{Cr}$ and $\mathrm{Pb}$ respectively migrated from the black polyethylene bag into posho during heating at the different treatment temperature. This showed that Co migrated most followed by $\mathrm{Cd}$ then $\mathrm{Cr}$ and $\mathrm{Pb}$ last. The amount of heavy metal decreased as the centroid of posho cube was approached for all heavy metals.

The surface $(0.5 \mathrm{~cm})$ in contact with the polyethylene bag produced the highest heavy metal contamination and the contamination decreased towards the centroid $(0.5>1.0 \mathrm{~cm}$ $>1.5 \mathrm{~cm}$ ) of the posho cube for each treatment temperature and holding time.

As highlighted by [14] that there is no contact material which is completely inert and so there is a possibility of their chemical constituents migrating into the packaged food, it was observed in this study as varying concentrations of heavy metals migrated into posho wrapped in polyethylene bag during heating.

Though $\mathrm{Pb}$ migrated highest followed by $\mathrm{Cr}$, then $\mathrm{Cd}$ and Co last, the reverse order is true when their highest migrated concentrations into posho are compared to their initial concentrations in the black polyethylene bag. This might be

Table 5. Heavy metal migration into posho at treatment temperature, $\mathbf{T}_{2}$.

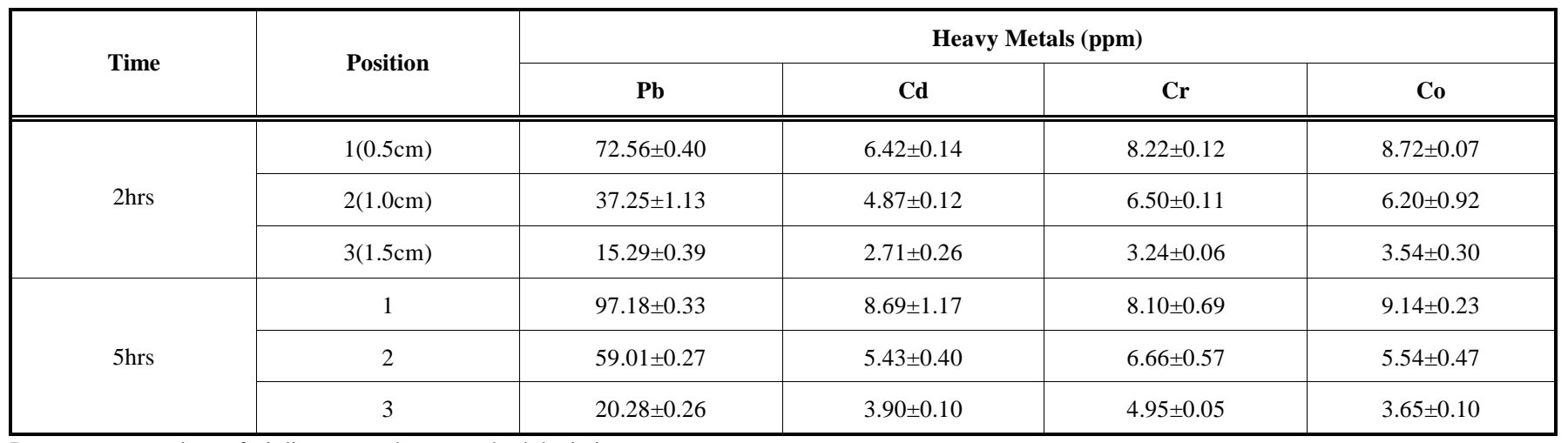

Data are mean values of triplicate samples \pm standard deviation.

Table 6. Heavy metal migration into posho at treatment temperature, $T_{3}$.

\begin{tabular}{|c|c|c|c|c|c|}
\hline Time & Position & \multicolumn{4}{|c|}{ Heavy Metals (ppm) } \\
\hline \multirow{2}{*}{$2 \mathrm{hrs}$} & $2(1.0 \mathrm{~cm})$ & $74.72 \pm 0.90$ & $6.17 \pm 0.24$ & $5.03 \pm 0.47$ & $10.28 \pm 0.50$ \\
\hline & $3(1.5 \mathrm{~cm})$ & $28.47 \pm 0.47$ & $3.78 \pm 0.02$ & $3.81 \pm 0.02$ & $4.28 \pm 0.20$ \\
\hline \multirow{2}{*}{$5 \mathrm{hrs}$} & 2 & $78.82 \pm 0.83$ & $7.14 \pm 0.08$ & $5.80 \pm 0.11$ & $11.25 \pm 0.23$ \\
\hline & 3 & $34.63 \pm 0.14$ & $3.81 \pm 0.02$ & $3.85 \pm 0.03$ & $6.55 \pm 0.05$ \\
\hline
\end{tabular}


attributed to Co having better diffusion and partition coefficients as well as being more soluble in posho than $\mathrm{Cd}$, $\mathrm{Cr}$ and $\mathrm{Pb}$.

Furthermore, Co partitioning well into posho may have created a smooth and continuous concentration profile which facilitated its rate of migration compared to other heavy metals that might have partitioned poorly into posho creating a discontinuous concentration profiles thus retarding their rates of migration into posho [9].

Generally, migration of heavy metals from the black polyethylene bags into posho was poor compared to their initial concentrations in the black polyethylene bag (Table 1). This might be due to the fact that posho is solid and less in fats into which most of the polyethylene additives are soluble hence hindering their migration. Though the migrated heavy metal concentrations are low, over a long period of time they are known to accumulate in the body causing adverse effect to human health therefore the practice of wrapping food into polyethylene bags should be avoided.

\subsection{To Educate and Engage the General Public About Food Contamination}

In an effort to make the research findings from this study more relevant to the general public, different avenues were used to convey its outcomes. The findings were published in print media and television interviews. Further, different users of these polyethylene bags have already been engaged both at house hold and market level and brochures in local languages were also been printed to aid the process of dissemination.

\section{CONCLUSION}

Results in this study indicated that both black and green polyethylene bags contained heavy metals namely; $\mathrm{Pb}, \mathrm{Cd}$, $\mathrm{Cr}$ and $\mathrm{Co}$ in varying concentrations which migrated into food during cooking at different temperatures and their migration increased with increase in temperature and holding time. Therefore this exposes people who eat food wrapped in polyethylene bags during cooking to ingesting heavy metals, though in small quantities, over a long period of time they may be faced with a cascade of health complications. However, with regard to polyethylene bag manufacture and use, Uganda, unfortunately does not have any enforceable standard for the total content of $\mathrm{Pb}, \mathrm{Cd}, \mathrm{Cr}$ and $\mathrm{Co}$ in polyethylene bags. Therefore, this calls for immediate intervention by responsible stakeholders to devise ways so that the practice of wrapping foods in polyethylene bags is put to an end.

\section{CONFLICT OF INTEREST}

The authors confirm that this article content has no conflicts of interest.

\section{ACKNOWLEDGEMENTS}

This work was supported by Project RU/CGS/GRG/15/10/10 the RUFORUM, Kampala, Uganda. The scientific responsi-bility is assumed by its authors.

\section{REFERENCES}

[1] Philip T. Polyethylene for food packaging application. Int Life Sci Inst report series 2003

[2] Kanetkar V, Sajilata M, Singhal R, Savitha K. Scalping of flavors in packaged foods. Comprehensive Review, Food Sci Food Safe 2007; 6: 17-35.

[3] Kigozi J, Mulwana C, Banadda N. Assessing the level of chemical contaminant migration associated with cooking foods in polyethylene bags: a case study of Ugali. Afr J Food Sci 2010; 4: 10.

[4] Cruz J, Silva S, Garcia R, Franz R, Losada P. Studies of mass transport of model chemicals from packaging into and within cheeses. J Food Eng 2008; 87: 107-15.

[5] Castle L. Chemical migration into food: an overview. In: Barnes A, Sinclair C, Watson D, Eds. Chemical migration and food contact materials. Woodhead publishing limited: Cambridge 2007; p. 3.

[6] Zygoura D, Goulas A, Riganakos A, Kontominas M. Migration of di (2- ethylhexyl) adipate and acetyltributyl citrate plasticizers from food grade PVC film into isooctane: effect of gamma radiation. J Food Eng 2007; 78: 870-7

[7] Coyle P, Kosnett J, Hipkins K. Severe Lead poisoning in the plastic industry: a report of three cases. Am J Indus Med 2005; 47: 172-5.

[8] Ogunfowokan A, Morakinyo M, Agboola O. Levels of lead and cadmium in some Nigerian confection wrappers. J App Sci 2005; 5: 1032-5.

[9] Lau W, Wong S. Contamination in food from packaging material. J Chromatograph A 2000; 882; 255-70.

[10] Bakircioglu D, Bakircioglu Y, Ucar G. Determination of some metal levels in cheese samples packaged in plastic and tin containers by ICP-OES after dry, wet and microwave digestion. Food Chem Toxicol 2011; 49: 202-7.

[11] Chove B, Ballegu W, Chove L. Copper and Levels in two popular leafy vegetable grown around Morogoro Municipality, Tanzania. Tanzania Health Res Bullet 2006; 8: 1.

[12] Okalebo J, Gathau K, Woomer L. Laboratory methods of soil and plant analysis (second edition). SACRED Africa: Nairobi 2002.

[13] Omolaoye J, Uzairu A, Gimba C. Heavy metal assessment of some soft plastic toys imported into Nigeria from China. J Environm Chem Ecotoxicol 2010; 8: 126-30.

[14] Castle L. Chemical migration from food packaging. In: Watson D, Ed. Food chemical safety. Volume 1: Contaminants. Woodhead Publishing limited: Cambridge 2001; pp. 193-4. 